\title{
Characteristics of open globe injuries in geriatric patients
}

\author{
Geriatrik hastalarda açık göz küresi yaralanmalarının özellikleri
}

\author{
Levent TÖK, ${ }^{1}$ Özlem YALÇIN TÖK, ${ }^{1}$ Dilek ÖZKAYA, ${ }^{2}$ Elif ERASLAN, ${ }^{3}$ \\ Yonca SÖNMEZ, ${ }^{4}$ Firdevs ÖRNEK, ${ }^{3}$ Yavuz BARDAK ${ }^{1}$
}

\section{BACKGROUND}

We aimed to evaluate the etiological and demographic characteristics of open globe injuries in geriatric patients, to determine the factors affecting the prognosis and to discuss the differences between geriatric and young populations in light of the current literature.

\section{METHODS}

The medical files of 30 patients aged 65 years and older who were treated and followed up for open globe injuries between 1998 and 2009 were evaluated retrospectively.

\section{RESULTS}

The mean age was 73.1 years. Sixty percent of the patients were male, with a predominance of left eye involvement. The most common type of trauma was rupture due to a blunt object. The presenting visual acuity was no light perception in 13 patients, light perception/hand movement in 15 patients and 1/200-19/200 in 2 patients. In a univariate analysis assessing the effects of demographic and clinical characteristics on final vision, the wound location, type of trauma and Ocular Trauma Score were found to be statistically significant variations.

\section{CONCLUSION}

The prognosis of open globe injuries is very poor in geriatric patients. Age-related structural changes and previous history of surgeries contribute to easy development of a rupture. During the treatment process, limited recovery capacity, ocular pathology in patients and low functional capacity in this age group exert negative effects on the prognosis.

Key Words: Elderly; open globe injury; penetrating injury; rupture.

\section{AMAÇ}

Açık göz küresi yaralanması olan geriatrik hastaların demografik ve etyolojik özelliklerini değerlendirmeyi, prognozu etkileyen faktörleri tespit etmeyi ve güncel literatür eşliğinde genç nüfusla farklılıkları karşılaştırmayı amaçladık.

\section{GEREÇ VE YÖNTEM}

Açık göz küresi yaralanması nedeniyle 1998-2009 yılları arasında tedavisi ve takibi yapılan 65 yaş üzerinde 30 hastanın dosyaları geriye dönük olarak değerlendirildi.

\section{BULGULAR}

Ortalama yaş 73,1 yıl idi. Hastaların \%60'1 erkekti ve en fazla sol göz tutulumu vardı. En sik rastlanan travma tipi künt nesnelerle oluşan yırtılma idi. Hastaların başvuru anındaki görme keskinlikleri 13 hastada ışık hissi yokken, 15 hastada 1şık hissi/el hareketleri, 2 hastada 1/20019/200 düzeyindeydi. Demografik ve klinik karakteristiklerin final görme keskinliği üzerine etkisinin değerlendirildiği tek değişkenli analizde yara yeri, travma tipi ve oküler travma skoru istatistiksel olarak anlamlı değişkenlerdi.

\section{SONUÇ}

Açık göz küresi yaralanmalarının prognozu geriatrik hastalarda oldukça kötüdür. Yaşa bağlı gelişen yapısal değişiklikler, geçirilmiş cerrahiler daha kolay yırtık gelişimine neden olmaktadır. Tedavi sürecinde iyileşme kapasitesinin s1nırlı olması, hastaların beraberlerinde bulunan göz patolojileri ve fonksiyonel kapasitenin bu yaş grubunda düşük olması prognozu kötü yönde etkilemektedir.

Anahtar Sözcükler: Yaşl1; açık göz küresi yaralanması; penetran yaralanma; rüptür.
Departments of ${ }^{1}$ Ophthalmology, ${ }^{4}$ Public Health, Süleyman Demirel University, Faculty of Medicine, Isparta; ${ }^{2}$ Department of Ophthalmology, Isparta State Hospital, Isparta; ${ }^{3}$ Department of Ophthalmology, Ankara Training and Research Hospital, Ankara, Turkey.
Süleyman Demirel Üniversitesi Tıp Fakültesi, ${ }^{1}$ Göz Hastalıkları Anabilim Dalı, ${ }^{4}$ Halk Sağlığı Anabilim Dalı, Isparta; ${ }^{2}$ Isparta Devlet Hastanesi, Göz Hastalıkları Kliniği, Isparta; ${ }^{3}$ Ankara Eğitim ve Araştırma Hastanesi, Göz Hastalıkları Kliniği, Ankara. 
Open globe injury is a common cause of visual impairment and blindness. Ocular trauma is an important, worldwide and preventable public health problem. ${ }^{[1]}$ The cost of ocular trauma to society is related to medical treatment as well as expenditures associated with workers' compensation, lost days of work and production time. ${ }^{[2]}$ These injuries have a global incidence rate of approximately 3.5 per 100,000 persons annually, which leads to an estimated 203,000 open globe injuries every year worldwide. ${ }^{[3]}$ Patients with eye injuries are usually young, and children account for $20-50 \%$ of all ocular injuries. ${ }^{[4-6]}$ Usha $\operatorname{Vasu}^{[7]}$ found $81 \%$ of patients aged under 45 years. Patients aged 50 and above constituted $6.7 \%$ of the ocular trauma group in the study by Üstündag et al. and $15.2 \%$ in the study by Soylu et al. ${ }^{[8,9]}$ There are no data regarding ocular trauma in elderly patients in the current literature.

The purpose of this retrospective study was to determine epidemiological and clinical characteristics and outcome of serious eye injuries in Turkish patients aged 65 years and older who presented to an emergency department of a referral ophthalmologic service.

\section{MATERIALS AND METHODS}

This study was approved by the Local Ethics Committee of our institution. A review of all cases of open globe injuries who presented to the emergency unit of the Ophthalmology Department of Ankara Training and Research Hospital and Süleyman Demirel University between January 1998 and January 2009 was undertaken. The chart of each patient was reviewed to obtain data including a history of ocular injury, patient demographics (age and sex), involved eye, date of injury, anatomic location of injury, cause of injury, presenting visual acuity, and clinical signs (the presence of a relative afferent pupillary defect (RAPD), endophthalmitis, hyphema, uveal tissue and vitreous prolapse, traumatic cataract, vitreous hemorrhage, retinal detachment, intraocular foreign body, and eyelid laceration). The outcome was evaluated in terms of final best-corrected (Snellen) visual acuity, measured at the last visit. The definition and classification of ocular trauma in this study were modified from the Ocular Trauma Classification Group guidelines and Birmingham Eye Trauma Terminology. ${ }^{[10,11]}$ Open globe injuries were classified into four categories as: globe ruptures, penetrating injuries, intraocular foreign body injuries, or perforating injuries. Wound location was defined as zone I if the injury was confined to the cornea including the corneoscleral limbus, as zone II if the injury was located in the corneoscleral limbus to a point $5 \mathrm{~mm}$ posterior into the sclera, and as zone III if the injury was located in the sclera posterior to zone II.

In a study of 2500 patients by Kuhn et al., ${ }^{[12]}$ the Ocular Trauma Score (OTS) was calculated accord- ing to the presenting findings of patients. The OTS was calculated by assigning a raw point value for the initial visual acuity (no light perception (NLP), light perception (LP)/hand motion (HM), 1/200-19/200, 20/200-20/50, and $\geq 20 / 40$ ) and then subtracting the appropriate raw points for each diagnosis of globe rupture, endophthalmitis, perforating injury, retinal detachment, and a RAPD (Table 1). Based on the severity of the trauma, a score ranging between 0 and 100 is obtained. A low score is usually obtained after a severe trauma, which is indicative of a poor prognosis. In order to allow for an easy assessment in conformity with the OTS, presenting and final visual acuities were grouped into 5 as NLP, LP/HM, 1/200-19/200, $20 / 200-20 / 50$ and $\geq 20 / 40$.

\section{Statistical Analysis}

Data were analyzed with SPSS version 15.0 (SPSS, Inc., Chicago, IL, US). Statistical analysis of quantitative data, including descriptive statistics, parametric and non-parametric comparisons, was performed for all variables. Frequency analysis was performed using the chi-square test. Univariate chi-square analysis was performed on the variables of age, gender, cause of injury, mechanism of injury, wound location, presenting visual acuity, type of injury, OTS category, presence or absence of eyelid laceration, retinal detachment, a RAPD, endophthalmitis, vitreous prolapse, hyphema, lens damage, and uveal tissue prolapse to determine which of these was associated with visual outcome. In the univariate analysis, patients were divided into two groups as those with a final visual acuity of HM or worse and those with a final visual acuity better than HM. All P-values were two-sided, and a p-value less than 0.05 was considered statistically significant.

\section{RESULTS}

A total of 30 patients with open globe injuries were enrolled in this study (18 [60\%] male; $12[40 \%]$ female). Seventeen (56.7\%) left eyes and $13(43.3 \%)$

Table 1. Calculating the Ocular Trauma Score: variables and raw points

\begin{tabular}{lc}
\hline Variables & Raw points \\
\hline Initial vision & \\
$\quad$ NLP & 60 \\
LP/HM & 70 \\
$1 / 200-19 / 200$ & 80 \\
$20 / 200 / 20 / 50$ & 90 \\
$\geq 20 / 40$ & 100 \\
Rupture & -23 \\
Endophthalmitis & -17 \\
Perforating injury & -14 \\
Retinal detachment & -11 \\
Afferent pupillary defect & -10 \\
\hline
\end{tabular}


Table 2. Cause of injury

\begin{tabular}{lc}
\hline Cause of injury & $\mathrm{n}(\%)$ \\
\hline Blunt injury with wood & $8(26.7)$ \\
Branch of a tree or a plant & $6(20)$ \\
Fall & $4(13.4)$ \\
Animal & $4(13.4)$ \\
Fist & $2(6.7)$ \\
Glass & $2(6.7)$ \\
Stone & $1(3.3)$ \\
Metal & $1(3.3)$ \\
Traffic accident & $1(3.3)$ \\
Hammer on metal nail & $1(3.3)$ \\
\hline
\end{tabular}

Table 3. Place of injury

\begin{tabular}{lc}
\hline Place of injury & $\mathrm{n}(\%)$ \\
\hline Farm & $19(63.3)$ \\
Outdoors & $5(16.7)$ \\
Home & $5(16.7)$ \\
Street & $1(3.3)$ \\
\hline
\end{tabular}

right eyes were involved. The mean $( \pm$ standard deviation) age of the patients was $73.06 \pm 5.99$ years, with a range of 65-84 years.

Rupture was the most common type of open globe injury, with 17 eyes $(56.7 \%)$. The mechanisms of injury are shown in Table 2 . Injuries were most frequently caused by a blunt object such as wood, stone or metal, during a fist assault, or by an animal while milking. Most of the traumas were caused by a large wood chip flying into the eye while chopping. $63.3 \%$ of all injuries occurred on a farm (Table 3 ).

Of the falls, 3 patients slipped in the bathroom and hit their head/eye on the side of the washbasin or faucet, while 1 patient with hypotension fell after getting out of the bed abruptly at night, hitting the side of the bed.

Thirty percent (n: 9) of open globe injuries were zone I, 36.7\% (n: 11) zone II and 33.3\% (n: 10) zone III. Presenting visual acuity was NLP in $13(43.3 \%)$ patients, LP/HM in $15(50 \%)$ patients and $1 / 200$ $19 / 200$ in $2(6.7 \%)$ patients. We observed retinal detachment in 6 patients, the presence of a RAPD in 6 , lens damage in 10, uveal tissue prolapse in 11, hyphema of varying degrees of severity in 12 , vitreous hemorrhage in 9 , and eyelid laceration in 3 . Nine of the patients had a previous history of cataract surgery. Among these patients, rupture due to previous surgical incision was observed in 5 patients who had undergone large- incision cataract surgery, and it was found that the scar tissue extended to the sclera. No cases presented with post-traumatic endophthalmitis.
The follow-up period ranged between 6-85 months (mean: $24.73 \pm 24.56$ months), and final visual outcome was recorded at the last visit. The final visual acuity was NLP in $16(53.3 \%)$ patients, LP/HM in $8(26.7 \%), 1 / 200-19 / 200$ in $5(16.7 \%)$, and $20 / 200$ $20 / 50$ in $1(3.3 \%)$.

In the evaluation of the effects of demographic and clinical characteristics on final vision, the zone, type of trauma and OTS were found to be significant variations according to the univariate analysis (Table 4).

\section{DISCUSSION}

The United States population continues to age, with 37 million people $(12.4 \%)$ currently over the age of 65 , and 71 million (19.7\%) expected in this category by 2030. In 2005, almost 500 million (7.3\%) people worldwide were 65 and older. By 2030, this is expected to increase to almost 1 billion $(11.7 \%) .{ }^{[13]}$ A majority of the estimated 40 million blind individuals around the world are in the older age groups. Data on blindness and visual impairment are obtained primarily from blindness registries and prevalence surveys in different countries throughout the world. The qualities of these data vary dramatically between countries, and comparison of the results from different studies is difficult. However, all studies indicate an increase in the prevalence of visual loss and blindness with increasing age. ${ }^{[14]}$ In developing countries and Eastern countries, the most common cause of blindness is cataract and uncorrected refractive error, whereas in Western countries, the most common cause of blindness is agerelated macular degeneration among Caucasians and cataract and glaucoma among blacks. ${ }^{[15]}$ Even though trauma is the most important cause of unilateral blindness in the pediatric age group, it ranks low among the elderly population. Trauma in the geriatric age group differs from that in the young age group with regard to characteristics and prognosis.

In terms of gender, there is a marked predominance of males in studies including all age groups. ${ }^{[1,16-18]}$ However, this predominance disappears with advancing age. In this study, the male to female ratio was close to $1: 1$, whereas the number of females was found to be higher than that of males in a study by Andreoli et al. ${ }^{[19]}$ The predominance of males in ocular trauma among the young age group is a result of their spending more time outdoors, their employment in higher risk jobs, alcohol use, and participation in dangerous sports and hobbies, whereas the rate of risk for trauma approaches that for females with increasing age, since they eventually retire and lead a more sedentary life. We consider that the gap between genders closes with increasing age since people move to the country, and males and females work side by side in agricultural activities in our country. In this study, the 
Table 4. Univariate analysis of patient characteristics and final visual acuity

\begin{tabular}{|c|c|c|c|c|}
\hline \multirow[t]{2}{*}{ Variables } & \multicolumn{2}{|c|}{ Final visual acuity } & \multirow[b]{2}{*}{$\mathrm{p}$} & \multirow[b]{2}{*}{ Odds ratio $(95 \% \mathrm{CI})$} \\
\hline & Better than HM $(n=6)$ & NLP / HM (n=24) & & \\
\hline Age (years) & $73.83 \pm 6.85$ & $72.88 \pm 5.92$ & 0.722 & $0.97(0.84-1.13)$ \\
\hline \multicolumn{5}{|l|}{ Age groups (years) } \\
\hline $65-74$ & $3(50)$ & $11(45.8)$ & - & $1.000^{\mathrm{a}}$ \\
\hline $75-84$ & $3(50)$ & $13(54.2)$ & 0.605 & $1.143(0.273-4.778)$ \\
\hline Female/ref. Male & $4(66.7)$ & $8(33.3)$ & 0.184 & $0.25(0.037-1.668)$ \\
\hline Right/ref. Left & $2(33.3)$ & $11(45.8)$ & 0.672 & $1.692(0.259-11.07)$ \\
\hline \multicolumn{5}{|l|}{ ZONE } \\
\hline I & $5(83.3)$ & $4(16.7)$ & - & $1.000^{\mathrm{a}}$ \\
\hline II & $1(16.7)$ & $10(41.7)$ & 0.043 & $12.50(1.09-143.44)$ \\
\hline III & 0 & $10(41.7)$ & 0.04 & $25.67(1.16-568.94)$ \\
\hline \multicolumn{5}{|l|}{ Type of trauma } \\
\hline Penetrating injury & $6(100)$ & $7(29.2)$ & - & $1.000^{\mathrm{a}}$ \\
\hline Rupture & 0 & $17(70.8)$ & 0.026 & $30.33(1.51-609.87)$ \\
\hline \multicolumn{5}{|l|}{ Presenting visual acuity } \\
\hline NLP & $1(16.7)$ & $12(50)$ & 0.157 & $12.00(0.28-374.86)$ \\
\hline $\mathrm{LP} / \mathrm{HM}$ & $4(66.7)$ & $11(45.8)$ & 0.509 & $2.75(0.14-55.17)$ \\
\hline $1 / 200-19 / 200$ & $1(16.7)$ & $1(4.2)$ & - & $1.000^{\mathrm{a}}$ \\
\hline \multicolumn{5}{|l|}{ OTS Category } \\
\hline "1-2" & $2(33.3)$ & $19(79.2)$ & 0.043 & $7.6(1.068-54.092)$ \\
\hline “3” & $4(66.7)$ & $5(20.8)$ & - & $1.000^{\mathrm{a}}$ \\
\hline Retinal detachment & 0 & $6(25)$ & 0.213 & $6.70(0.34-133.60)$ \\
\hline Relative afferent pupillary defect & 0 & $6(25)$ & 0.400 & $3.67(0.18-75.75)$ \\
\hline Lid laceration & 0 & $3(12.5)$ & 0.635 & $2.12(0.10-46.53)$ \\
\hline Hyphema & $1(16.7)$ & $11(45.8)$ & 0.358 & $3.333(0.443-25.102)$ \\
\hline Uveal tissue prolapse & $2(33.3)$ & $9(37.5)$ & 0.620 & $0.833(0.126-5.504)$ \\
\hline Vitreous hemorrhage & 0 & $9(37.5)$ & 0.141 & $0.714(0.545-0.936)$ \\
\hline Lens damage & $3(50.0)$ & $7(29.2)$ & 0.372 & $3.00(0.473-19.04)$ \\
\hline
\end{tabular}

a: Reference category; CI: Confidence interval.

farm was the most common location of trauma, which supports this hypothesis. The location of trauma was noted as farm in $47.4 \%$ of the geriatric group patients in a study performed in our country. ${ }^{[8]}$ Unlike other age groups, rupture was the most common type of trauma in this study. The rate of injuries due to falls also increases in this age group. In a study by Andreoli et al., ${ }^{[19]}$ the rate of open globe injury due to falls was found to be $4 \%$ in the non-geriatric group and $65 \%$ in the geriatric group. This rate was found to be $13.4 \%$ in our study. Systemic hypertension, atherosclerotic diseases and dementia, which are common in the elderly population, also increase fall-related traumas. The prognosis is poor in fall-related traumas since blindness can develop in both eyes simultaneously. Additionally, poor final visual acuity after trauma further increases not only the risk of falls in geriatric patients but also the risk of trauma in the other eye and even the risk of multiorgan trauma.

Because the most common type of trauma was rupture, presenting findings and visual acuity were very poor. Presenting visual acuity was NLP in $43.3 \%$ of patients and $1 / 200-19 / 200$ in only 2 patients. Wound location tends to be zone I in young patients with open globe injuries, whereas wound is localized more posteriorly in zones II and III in the geriatric age group. In this study, $70 \%$ of patients had zone II-III traumas. Additionally, previous history of surgeries also worsens the prognosis in elderly patients. It was also found in our study that the incisional scar at the site of the previous surgery was ruptured and extended to the sclera in 5 patients, and there were no intraocular lenses in 2 patients with large-incision cataract surgery.

In this study, prognosis for traumas in the elderly population was found to be very poor. In the followups, a visual acuity of 1/200-19/200 or better was found in only $20 \%$ of patients. When the factors influencing final visual acuity were evaluated, remarkable differences were observed between other age groups. Previous studies of all age groups have emphasized a strong association between presenting visual acuity and final visual acuity. If the presenting visual acuity is good, so is the final visual acuity. However, in this study, no statistically significant correlation was found between 
presenting visual acuity and final visual acuity, which can be attributed in part to the small number of our patients. In this study, anatomic location of the wound, type of trauma and OTS were found to be statistically significant variations affecting the final visual acuity. After trauma to the posterior segment, prognosis was found to be poor. Zone II and zone III wound localizations increased the risk of a final visual acuity of HM or worse by 12.5- and 25.7-fold, respectively, when compared to wounds in zone I. A rupture-type injury increased a final visual acuity of HM or worse by 30 fold when compared to penetrating injuries. The risk of a final visual acuity of HM or worse was increased by 7.6-fold in patients with an OTS lower than 65 compared to those with a better OTS score.

In this study, the mean OTS was 50.1, whereas the median of the OTS category was found to be 2 . The OTS study is heterogeneous in that it was performed in all age groups with both open- and closed-globe trauma. For this reason, the correlation between final visual acuity and the OTS is not as strong in elderly patients as in other age groups. However, it was found to be important for the determination of the prognosis and prediction of final visual acuity in terms of informing the patient and the family, particularly within the first few hours of the trauma.

The rate of endophthalmitis after an open globe injury ranges between $4-12 \% \cdot{ }^{[20-22]}$ In this study, it is remarkable that although most of the injuries were caused by organic materials such as a wood chip and occurred in the country, no patient presented with endophthalmitis. In the literature, there are few or no examples of intraocular object in the geriatric age group, and the most frequent mechanism of trauma is rupture, which can be explained by a more posterior location of the wound (zone II or III). ${ }^{[19]}$

The enucleation rate is low despite poor final visual acuity in the geriatric age group. In our study, only three patients underwent enucleation. This can be explained by the fact that geriatric patients have lower aesthetic expectations than young patients, the risk of sympathetic ophthalmia is lower in the geriatric age group than in the young age group because of shorter life expectancy, and the presence of systemic diseases restricts the performance of additional surgical intervention.

In geriatric patients, some changes occur in the function and structure of the eye with advancing age. The incidence and prevalence of diseases such as agerelated macular degeneration, glaucoma and vascular occlusive diseases increase dramatically with age. Some of these changes are condensation of the vitreous gel, changes in corneal tonicity and sensitivity, scleral rigidity, ciliary body shape and tone, and lens selectivity. ${ }^{[23]}$ Age-related changes of the optic nerve include a decrease in the number of axons, axonal swelling at the level of the lamina cribrosa, thickening of the lamina cribrosa, and an increase in elastic fibers. ${ }^{[11]}$ Using HRF, Embleton et al. ${ }^{[24]}$ found a significant negative correlation between advancing age and retinal blood volume, neuroretinal rim blood velocity and lamina cribrosa blood volume. The retinal blood supply decreases in elderly subjects, and further implies a net increase in the resistance of the vascular bed and/ or decrease in the total functional vessel diameter. ${ }^{[13]}$ In addition, visual function changes include declining visual acuity and diminished visual field sensitivity. As a result of these changes, globe rigidity decreases and eye injuries can occur even after a mild trauma in the elderly population. In these patients with limited functional capacity, post-traumatic recovery cannot be achieved satisfactorily and the prognosis worsens.

In conclusion, prognosis is very poor after an open globe injury in the geriatric age group. Due to agerelated ocular changes, functional capacity is limited in patients aged 65 years and older. This capacity is further decreased by pre-existing ocular diseases. Because of age-related structural changes, open globe injuries can occur even after a mild trauma. In addition, previous history of ocular surgeries, particularly largeincision cataract surgery, decreases the resistance of the globe and contributes to easy development of a rupture after a trauma. The recovery capacity is low in these patients with systemic diseases. Additionally, geriatric patients with normal fellow eye usually do not accept to undergo further surgical interventions required after primary repair and do not receive sufficient rehabilitation because of their satisfaction with the outcome. Due to these above-mentioned characteristics, the geriatric age group is different in terms of both the etiology and the clinical characteristics of the trauma. Further comprehensive studies including large series of patients are required in order to determine the prognosis in these patients.

\section{REFERENCES}

1. Cillino S, Casuccio A, Di Pace F, Pillitteri F, Cillino G. A five-year retrospective study of the epidemiological characteristics and visual outcomes of patients hospitalized for ocular trauma in a Mediterranean area. BMC Ophthalmol 2008;8:6.

2. Knyazer B, Levy J, Rosen S, Belfair N, Klemperer I, Lifshitz T. Prognostic factors in posterior open globe injuries (zoneIII injuries). Clin Experiment Ophthalmol 2008;36:836-41.

3. Négrel AD, Thylefors B. The global impact of eye injuries. Ophthalmic Epidemiol 1998;5:143-69.

4. Punnonen E. Epidemiological and social aspects of perforating eye injuries. Acta Ophthalmol (Copenh) 1989;67:492-8.

5. Blomdahl S, Norell S. Perforating eye injury in the Stockholm population. An epidemiological study. Acta Ophthalmol (Copenh) 1984;62:378-90

6. Moreira CA Jr, Debert-Ribeiro M, Belfort R Jr. Epidemio- 
logical study of eye injuries in Brazilian children. Arch Ophthalmol 1988;106:781-4.

7. Vasu U, Vasnaik A, Battu RR, Kurian M, George S. Occupational open globe injuries. Indian J Ophthalmol 2001;49:43-7.

8. Üstündağ M, Orak M, Güloğlu C, Sayhan MB, Özhasenekler A. Göz yarlanması sonucu acil servise başvuran hastaların geriye dönük incelemesi. Türkiye Acil Tıp Dergisi 2007;7:647.

9. Soylu M, Sizmaz S, Cayli S. Eye injury (ocular trauma) in southern Turkey: epidemiology, ocular survival, and visual outcome. Int Ophthalmol 2010;30:143-8.

10. Pieramici DJ, Sternberg P Jr, Aaberg TM Sr, Bridges WZ Jr, Capone A Jr, Cardillo JA, et al. A system for classifying mechanical injuries of the eye (globe). The Ocular Trauma Classification Group. Am J Ophthalmol 1997;123:820-31.

11. Kuhn F, Morris R, Witherspoon CD, Heimann K, Jeffers JB, Treister G. A standardized classification of ocular trauma. Ophthalmology 1996;103:240-3.

12. Kuhn F, Maisiak R, Mann L, Mester V, Morris R, Witherspoon CD. The Ocular Trauma Score (OTS). Ophthalmol Clin North Am 2002;15:163-5.

13. Ehrlich R, Kheradiya NS, Winston DM, Moore DB, Wirostko B, Harris A. Age-related ocular vascular changes. Graefes Arch Clin Exp Ophthalmol 2009;247:583-91.

14. Hyman L. Epidemiology of eye disease in the elderly. Eye (Lond) 1987;1:330-41.

15. Wong TY, Loon SC, Saw SM. The epidemiology of age related eye diseases in Asia. Br J Ophthalmol 2006;90:506-11.
16. Williams DF, Mieler WF, Abrams GW, Lewis H. Results and prognostic factors in penetrating ocular injuries with retained intraocular foreign bodies. Ophthalmology 1988;95:911-6.

17. Rao LG, Ninan A, Rao KA. Descriptive study on ocular survival, visual outcome and prognostic factors in open globe injuries. Indian J Ophthalmol 2010;58:321-3.

18. Rahman I, Maino A, Devadason D, Leatherbarrow B. Open globe injuries: factors predictive of poor outcome. Eye (Lond) 2006;20:1336-41.

19. Andreoli MT, Andreoli CM. Geriatric traumatic open globe injuries. Ophthalmology 2011;118:156-9.

20. Thompson WS, Rubsamen PE, Flynn HW Jr, Schiffman J, Cousins SW. Endophthalmitis after penetrating trauma. Risk factors and visual acuity outcomes. Ophthalmology 1995;102:1696-701.

21. Reynolds DS, Flynn HW Jr. Endophthalmitis after penetrating ocular trauma. Curr Opin Ophthalmol 1997;8:32-8.

22. Tran TP, Le TM, Bui HT, Nguyen TM, Küchle M, Nguyen NX. Post-traumatic endophthalmitis after penetrating injury in Vietnam: risk factors, microbiological aspect and visual outcome. Klin Monbl Augenheilkd 2003;220:481-5. [Abstract]

23. Salvi SM, Akhtar S, Currie Z. Ageing changes in the eye. Postgrad Med J 2006;82:581-7.

24. Embleton SJ, Hosking SL, Roff Hilton EJ, Cunliffe IA. Effect of senescence on ocular blood flow in the retina, neuroretinal rim and lamina cribrosa, using scanning laser Doppler flowmetry. Eye (Lond) 2002;16:156-62. 